\title{
Laporan Literatur Review
}

\author{
Oleh \\ (Muhammad Sabirin) \\ Program Studi Pendidikan IPS FKIP ULM
}

NIM

(1910111310017)

\section{Buku yang di review}

Susanto, H., \& Akmal, H. (2019). Media Pembelajaran Sejarah Era Teknologi Informasi (Konsep Dasar, Prinsi Aplikatif, dan Perancangannya).

\section{Ringkasan isi bab}

Media merupakan alat atau sarana yang memiliki fungsi menjadi perantara atau penyalur informasi dari pengirim ke penerima.Konsep ini menjelaskan bahwa segala jenis alat baik elektronik mapun non elektronik yang dapat menyampaikan informasi pembelajaran disebut dengan media.Menurut Rusman dan kawan kawan (2011: 170) media pembelajaran merupakan suatu teknologi pembawa pesan yang dapat du gunakan untuk keperluan pembelajaran :media pembelajaran merupakan sarana fisik untuk menyampaikan materi pembelajaran,sarana komunikasi dalam bentuk cetak maupun pandang dengar termasuk teknologi perangkat keras.Media memiliki peranan dalam meningkatkan kualitas pembelajaran.Apabila media digunakan secara tepat akan mampu membantu meningkatkan efektivitas pembelajaran kerena dapat menambah pengetahuan,mengubah sikap dan juga menenamkan keterampilan bagi penggunanya.Sebaliknya jika media yang di gunakan tidak sesuai dengan keaadaan atau katakanlah kurang tepat dengan materi,maka akan mempengaruhi keefektifan pembelajaran sehingga berdampak pada terhambanya pencapaian tujuan.Media memiliki kemampuan untuck mengatasi beberapa hambatan proses penyampaian informasi pembelajaran kepada peserta didik.(Verbalisme) kemampuan menggunakan kata kata dalam menyampaikan informasi atau menjelaskan sesuatu hal.(kekacauan penafsiran) kesalahpahaman ayau miskonsi dalam diri menafsirkan suatu informasi.(fokos peserta didik menjadi bercabang,keadaan seperti ini terjadi ketika peserta didik tidak menemukan ketertarikan terhadap pembelajaran.Kurangya respon,dalam kegiatan pembelajaran keadaan ini bisa terjadi kerena cara guru mengajar yang monoton.Keadaan lingkungan yang kurang menyenangkan,ini juga mempengaruhi keefektifian proses pembelajaran.Melalui berbagai pendapat yang di paparkan,dapat disimpulkan bahwa media pembelajaran memiliki banyak kegunaan baik dari sundut pandang peserta didik sebagai 
pembejar.akan tetapi,media dapat dikatakan berguna apabila guru dan peserta tidak salah memilih media mana yang tepat untuk menunjang kegiatan pembelajaran yang berlangsung saat ini.Arsyad Azhar (2011:16) mengutip dari Livie \& Lentz (1982) mengemukakan empat fungsional media pembelajaran,yiatu (a)Fungsi atensi (b)Fungsi Aktif(c)fungsi kognitif (d)fungsi kompensatoris.Fungsi atensi yaitu menarik dan mengarahkan peserta didik untuk berkonsentrasi kepadaisi pelajaran yang berkiatan dengan makna visual yang di tampilkan atau menyertai teks pelajaran,fungsi afektif media pembelajaran dapat di lihat dari sikap dan tingkat kenyamanan peserta didik ketika belajar.fungsi kognitif terlihat dari temuan temuan penelitian yang mengingat informasi yang terkandung dalam pembelajaran.Fungsi kompensatoris media pembelajaran untuk mengakomodasi peserta didik yang lemah menerima pesan dan memahami isi pelajaran yang disajikan dengan teks atau verbal.

Dalam Bab II berisip penjelasan tentang langkah langkah melakukan analisis kebutuhan media,konseptualisasi media dan multimedia pembelajaran yang relevan dalam pembelajaran sejarah di SMA pada bab ini juga dilengkapi dengan latihan dan penugasan untuk memperdalam pemahaman mahasiswa.dan merupakan Guindance atau arah pencapaian dominan kognitif dan pisikomotorik untuk penguasaan kompetensi secara menyeluruh yang di paparkan di buku ajar. Pada bab III berisi penjelasan dan panduan menggunakan dan merencang media pembelajarab,dari sisi materi ajar,bab ini terdiri dari dua materi pokok yakni penggunaan media pembelajaran yang telah tersedia secara online dan merancang pembelajaran berbasis,smartphone.pada bagian pertama membahas tentang media pembelajaran yang tersedia online.dan pada bagian kedua di pandu untuk merancang dan melakukan kostomisasi media pembelajaran berbasis smartphone.

\section{Media digital untuk pembelajaran era pandemic Covid-19}

Banyak pendapat mengenai fungsi dan kegunaan media belajar yang membantu siswa untuk melakukan aktifitas pembelajaran,dalam media pembeajaran ada pembagian klasifikasi pembagain media,yaitu media yang digunakan secara umum dan media yang digunakan secara pribadi,terkhusus adanya media cetak dan media smartphone sangatlah membantu saat kita harus tetap melaksanakan proses pembelajaran meskipun harus di tempat yang berbada beda,media yang di gunakan smartphone yang selalu terhubung ke dunia maya,sehingga bisa mengakses apa saja hal yang baru dia dapati dan memberikan pengajaran berbasis online.Media mempunyai nilai praktis untuk membangkitkan motivasi belajar,membuat konsep abstrak menjadi konkret,misalnya menjelaskan tehap tahap sejarah melalui film grafik,mengatasi batas batas ruang kelas dalam menampilkan objek yang terlalu besar seperti candi,dan dapat pula mengatasi perbedaan pengalaman pribadi murid yang satu dengan yang lainnya,media juga dapat menampilkan objek yang terlalu kecil dan langka untuk dinakmati langsung.Ketika era pendemic ini media digitas

yang digunakan untuk proses pembelajaran.Media pembelajaran sejarah yang dapat digunakan 
mulai dari gambar,slide,poster,peta dan akan lebih baik apabila menggunakan multimedia.serta media berbasih teknologi seperti internet kerena didalamnya peserta didik dapat menggabungkan beberapa media yang telah di sebutkan tadi.Tentunya untuk terhubung ke dunia maya atau internet harus ada media atau alat pendukung seperti gadged,termasuk didalamnya laptop,handphone,netebook, Tablet,PC,DLL

Penggunaan media Internet dan alat penunjang lainnya seperti smartphone/laptop dalam suasana pandemic seperti sekarang ini adalah hal yang sudah menjadi kebiasaan baru untuk siswa dan guru dalam proses pembelajaran,dikernakan harusnya pembelajaran dilaksanakan Take Home dan dilarang luring,mengaharuskan mereka harus daring di tempat yang berbeda beda,dan itupun juga sangat efektif untuk mengisi kekosongan pembelajaran ketika tidak bisa bertemu langsung,dan pembelajaran ini sangat meefeseinsi keadaaan yang sedang terjadi.

\section{Simpulan}

Media pembelajaran merupakan segala sesuatu yang dapat di fungsikan untuk menyampaikan pesan dalam pembelajaran.Media mempunyai nilai praktis untuk membangkitkan motivasi belajar,membuat konsep abstrak menjadi konkret,dan juga membatasi keterbatasan keterbatasan dalam aktifitas instruksional tersebut.Media pembelajaran mengalami perkembangan pesat di era teknologi informs,tidak terkecuali dalam pembelajaran sejarah.Media pembelajaran di era teknologi informasi,tidak terkecuali dalam pembelajaran sejarah.Terdapat berbagai pilihan media pembelajaran sejarah yang dapat di gunakan atau dirancang oleh guru.media tersebut dapat berupa digitas ataupun analog.media analog dapat berupa benda atau peninggalan yang sudah ada tinggal digunakan ataupun media baru harus di rancang.sedangkan media digital dapat harus berupa aplikasi,konten internet,dokomentar maupun media digital yang harus di rancang atau kostomisasi oleh penggunanya.Media pembelajaran Sejarah yang dirancang di pembahasan ini merupakan media berbasis mobile smartphone.Setiap tahunnya dalam pembuatan media tersebuat memerlukan objek penelitian atau pengkajian untuk meperoleh data terkait kebutuhan media dan uji coba media.Terdapat berbagai tahapan dalam perencanaan media pembelajaran sejarah.Dimulai dari analisis kebutihan,penentuan media,ujicoba media,dan evaluasi terhadap media yang di uji coba.

\section{Referensi}

Susanto, Heri \& Akmal, Helmi. 2019. Media Pembelajaran Sejarah Era Teknologi Informasi (Konsep Dasar, Prinsip Aplikatif, dan Perancangannya). Banjarmasin: Program Studi Pendidikan Sejarah Fakultas Keguruan dan Ilmu Pendidikan Universitas Lambung Mangkurat. 